\section{Guidelines for Library and Information Services to Older Adults}

The American Library Association has a longstanding record of promoting library and information services to older adults. These guidelines, first developed in the 1970s, have been updated to respond to the changing demographics of an aging U.S. population. In 2007, one of every five persons was 55 years or older, or over 68 million people. The aging of the "baby boomers" will add to these numbers well into the next decade, and the lengthening of the average lifespan is creating several generations of older adults at a time that the United States has become more ethnically and linguistically diverse. As a result, the current population of older adults is the most heterogeneous in U.S. history. These updated guidelines reflect a basic principle in library services to older adults that recognizes this diversity and discourages stereotyping in planning collections, programs, and services for this growing population.

For purposes of these guidelines, an "older adult" is defined as a person at least 55 years old.

The updating of these guidelines began in 2005. Current and past members of the Committee on Library Service to an Aging Population and the Office of Literacy and Outreach Services (OLOS) Library Service to the Aging Subcommittee contributed to this revision.

\section{GUIDELINES FOR LIBRARY AND INFORMATION SERVICES TO OLDER ADULTS}

\subsection{Acquire current data about the older population and incorporate it into planning and budgeting.}

1.1 Conduct surveys on a regular basis of the older population and the aging service providers in the community, including their numbers, demographic characteristics, and other information, such as their location and housing; educational, socioeconomic, and ethnic background; religious organizations and other groups to which they belong; agencies that serve them; and the local media that targets older adults in the community.

1.2 Supplement surveys with focus groups and user studies among the community's older population to determine their needs and interests and to gauge how services, collections, and programs might be made more appropriate and relevant to this population.

1.3 Collect data on the specific and varied information needs 


\section{GUIDELINES FOR LIBRARY AND INFORMATION SERVICES TO OLDER ADULTS}

of older adults due to language, culture, education, income, Internet skills and access, gender identity/expression, sexual orientation, and age.

1.4 Utilize the above data in combination with the more general informational needs basic to older adults in their everyday lives. Such subjects include: health, health care, social security, financial planning, housing, independent living, elder law, caregiving (including grandparenting), lifelong learning (including adult literacy and computer skills), community service, civic engagement, and volunteering. The library's collections, programs, and informational services should reflect the diverse interests and needs of older adults.

1.5 Ensure that any services that target older adults are an integral and ongoing part of the library's operations and budget. Additional funding may be required for collections, accessibility equipment/software, and the time expended by library staff in services to older adults and community. If a special grant or external funding is sought to support a pilot or demonstration program, consider how the program will be integrated into the library's regular budget and services at the end of the grant.

1.6 Involve older adults in the library's planning process by establishing an advisory committee. This committee might include older adults who are regular library users; library volunteers, staff, board members, or members of the library's Friends group; and leaders of organizations of older adults and other community organizations.

\subsection{Ensure that the special needs and interests of older adults in your community are reflected in the library's collections, programs, and services.}

2.1 Appoint a librarian to act as a coordinator of services to older adults, ensuring that there is at least one designated staff member monitoring and developing the library's collections and services with older adults in mind.

2.2 Consider how the library can be made more visible, more welcoming, and more relevant to older adult users.

2.3 Advertise the library's services and website in local newspapers, magazines, radio, or television programs that target older adults, and in senior centers, nutrition programs, and residential housing.

2.4 Offer to speak to organizations of older adults about the library's services on a regular basis.

2.5 Establish an ongoing liaison with agencies that serve older adults (especially senior centers that employ activity coordinators) to explore cooperative programming, recruit volunteers or friends of the library, and seek suggestions for programs or services that would encourage library use.

2.6 Work with state library agencies that may provide staff training and development and information resources for older adults.

\subsection{Make the library's collections and physical facilities safe, comfortable, and inviting for all older adults.}

3.1 Evaluate your library's accessibility by older adults with physical, visual, aural, reading, and other disabilities, according to the Accessibility Guidelines for Buildings and Facilities of the Americans with Disabilities Act.

3.2 Consider providing at least one wheelchair in the library for public use.

3.3 Accommodate users for whom prolonged standing is difficult by placing chairs or stools near stacks, information desks, check-out areas, computer terminals, and other areas. If possible, create a "Senior Space," using easy chairs gathered in an area adjacent to books and magazines of interest to older adults.

3.4 Consider placing materials frequently used by older adults on easily accessible shelves.

3.5 Place paperbacks, clearly labeled and well spaced, in areas of the library that are especially well lit, accommodating older adults who prefer paperbacks over heavier and more cumbersome hardback books.

3.6 Assure that spacing between shelving accommodates users in wheelchairs.

3.7 Ensure that signage is clear, Brailled (where appropriate), and readily visible to all, including users in wheelchairs. Library brochures should be in at least 14-point font type.

3.8 Provide at least one computer station prominently labeled and installed with large type software for older adults with low-vision. If needs warrant and resources are available, acquire other assistive technology such as a stand-alone Reading Machine that speaks the book's text to a blind reader; speech synthesizer and related software; low-tech magnification; and other devices.

3.9 Provide TTY access, closed-captioned videotapes, and assistive listening systems to older adults with hearing disabilities.

3.10 Acquire and make available books and periodicals in large print. 


\subsection{Make the library a focal point for information services to older adults.}

4.1 Cooperate with local Area Agencies on Aging, senior nutrition programs, senior volunteer programs, and others in the aging service provider network by advertising their service and making their publications and other information more readily accessible. The library can provide an invaluable service by organizing and consolidating information about government and community programs and services available to older adults.

4.2 Consider developing or expanding the library's website to provide links to the sites of organizations of older adults, government departments and agencies serving older adults, newspapers and other websites whose focus is older adults.

4.3 Ensure that the library's collection includes materials that are pertinent for caregivers of older adults, for their children or other family members, and for professional caregivers in the community.

\subsection{Target the older population in library programming.}

5.1 Incorporate adequate funding for programs, materials, and services for older adults in the library's operating budget, and actively seek supplemental funding through partnerships with other agencies, organizations, and foundations interested in serving older adults.

5.2 Plan programs each year that specifically target older adults and enhance their ability to remain independent and skillful library users. Publicizing such programs can heighten the library's visibility among the older population.

5.3 Select themes for programs that deal with specific interests of older adults identified through user surveys, focus groups, or circulation statistics reflecting borrowing patterns by older adults.

5.4 Plan programs for specific age groups or generations within the older population, being aware that interests and information needs vary greatly.

5.5 Include intergenerational programs and participate in intergenerational projects sponsored by others in the community. Consider partnerships with local schools, daycare facilities, or community organizations.

5.6 Pursue other opportunities for cooperative programming with partners such as community and senior centers; Area Agencies on Aging and other community agencies; and educational institutions offering continuing educational programs for older adults. Cooperative efforts might involve active participation in planning and delivering programs, assistance in advertising programs, or providing book displays and booklists in conjunction with the library's programs.

5.7 Consider providing computer and Internet courses specifically designed for older adults to accommodate a slower pace of instruction, provide sufficient time to develop "mousing skills," and allow for the possibility that some older adults may have visual, physical, or hearing disabilities. If possible, include individual tutoring provided by peers or others.

5.8 Explore opportunities to provide library services and programming to older adults outside the library, such as in senior or community centers, nursing homes, and senior housing units. Consider offering computer and Internet training in these locations.

5.9 Use library displays to combat ageism or the stereotypes in our society about older adults.

5.10 Provide opportunities for older adults to volunteer in the library.

5.11 Create opportunities for lifelong learning programs.

\subsection{Reach out to older adults in the community who are unable to travel to the library.}

6.1 Survey community needs and consider library budget planning to accommodate possible increases in demand for outreach services such as delivery of library materials by mail and mobile library services. Analyze community demographics, population forecasts, and housing trends to plan to meet this need effectively.

6.2 Offer the library's services to assistive living, alternative housing, senior day care, congregate meals sites, senior community centers, nursing homes, and senior residential or care homes in the community. Also offer assistance to older adults who are confined to private residences or who are unable to carry library materials home.

6.3 Advertise the library's services through local media, public health agencies, and other agencies that work with older adults.

6.4 Eliminate waiting lists for library services through innovative approaches to delivery of materials, a redistribution of personnel, or establishment of a volunteer delivery system. Partner with Regional Libraries for the Blind and Physically Handicapped to expand available services.

\subsection{Train the library's staff to serve older adults with courtesy and respect.}

7.1 Provide sensitivity training to staff at all levels to make them aware of difficulties older adults may have in using the 


\section{GUIDELINES FOR LIBRARY AND INFORMATION SERVICES TO OLDER ADULTS}

library, and how to make the library a more welcoming and comfortable place for older adults.

7.2 Train staff to recognize and combat ageism and stereotypes about older adults.

7.3 Ensure that all staff are aware of any special services the library offers that may be of interest to older adults, such as home delivery service, a talking books collection, a service to retrieve materials from the stacks, reading aids, or waiving of fines or fees.

7.4 Promote the employment of older adults as professional and support staff members.

\section{Bibliography}

Architectural and Transportation Barriers Compliance Board. ADA Accessibility Guidelines for Buildings and Facilities (ADAAG), 2002. www.access-board.gov/adaag/html/adaag.htm (accessed June 6, 2008).

Association for Library Service to Children, American Library Association. 2004. "Books for Children Portraying Aging and Older Characters in a Positive Light." www.gwumc.edu/cahh/booklist/ booklist_20041110.pdf (accessed June 6, 2008).

International Longevity Center (New York). 2006. Ageism in America. www.ilcusa.org/pages/publications/ageism-caregiving-sleep/ageism-in-america.php (accessed June 6, 2008).

Mates, Barbara T. 5-Star Programming and Services for Your 55+ Library Customers. Chicago: ALA, 2003.

Missouri State Library (Jefferson City, Missouri). 2002. Serving Seniors: A Resource Manual for Missouri Libraries. www.sos.mo.gov/library/ development/services/seniors/manual (accessed June 6, 2008).

Rubin, Rhea. Intergenerational Programming, a How-To-Do-It Manual for Librarians. New York: Neal-Schuman Publishers, 1993.

STATEMENT OF OWNERSHIP AND MANAGEMENT: Reference \& User Services Quarterly, Publication No 472-580, is published quarterly by the American Library Association (ALA), 50 E. Huron St., Chicago, Illinois 60611-2795. It is the official publication of the Reference and User Services Association, a division of ALA. Annual subscription price, \$65.00. American Library Association, 50 E. Huron St., Chicago, Il 60611-2795, owner; Reference and User Services Association, 50 E. Huron St., Chicago, IL 60611-2795, publisher; Diane Zabel, The Louis and Virginia Benzak Business Librarian, Schreyer Business Library, The Pennsylvania State University, 309 Paterno Library, University Park, PA 168021810, editor. Periodicals class postage paid at Chicago, Illinois, and at additional mailing offices. Printed in U.S.A. As a nonprofit organization authorized to mail at special rates (Section 423-12, Domestic Mail Manual), the purpose, function, and nonprofit status of this organization and the exempt status for federal income tax purposes has not changed during the preceding twelve months.

EXTENT AND NATURE OF CIRCULATION: ("Average" figures denote the average number of copies printed each issue during the previous twelve months. "Actual" figures denote actual numbers of copies of single issue published nearest to the filing date-Summer 2007 issue.) Total number of copies printed: Average, 6,558; Actual, 6,243. Sales through dealers, carriers, street vendors and counter sales: Average, 413; Actual, 382. Other classes mailed through the USPS: Average, none; Actual, none. Total paid and/or requested circulation: Average, 5,985; Actual, 5,845. Free distribution by mail, carrier, or other means, samples, complimentary and other free copies: Average, 271; Actual, 163. Total distribution: Average, 6,256; Actual, 6,008. Copies not distributed: office use, leftover, unaccounted, spoiled after printing: Average, 302; Actual, 235. Total (previous three entries): Average, 6,558; Actual, 6,243. Percent paid and/or requested circulation: Average, 95.67; Actual, 97.29. 